\title{
A case of epidermodysplasia verruciformis with poor response to cimetidine therapy
}

\author{
*Manouri Senanayake ${ }^{1}$, Mihira Manamperi ${ }^{2}$
}

Sri Lanka Journal of Child Health 2015; 44(4): 229-230

(Key words: Epidermodysplasia verruciformis, cimetidine therapy)

Epidermodysplasia verruciformis $(\mathrm{EV})$ is a very rare inherited skin disorder. It is characterized by widespread human papilloma virus (HPV) infection by both oncogenic and 'generally non-pathogenic' HPV types ${ }^{1}$. A high risk of squamous cell carcinoma is a recognized association ${ }^{2}$. The mode of inheritance is often autosomal recessive and an inactivating HP mutation in EVER1 or EVER2 genes located in chromosome 17 is the cause of the underlying cell mediated immune deficiency ${ }^{3,4}$. No specific therapy has yet been described. Cimetidine therapy is one therapeutic option that has been tried for its immune enhancing effects ${ }^{5}$. We report an eleven year old Sri Lankan girl with epidermodysplasia verruciformis who failed to respond to oral cimetidine (40 $\mathrm{mg} / \mathrm{kg} /$ day) given over five months.

\section{Case report}

An eleven year old girl was apparently well until six years of age when raised wart-like skin eruptions appeared on face, hands and legs. The lesions were flat-topped, fleshy, non-pruritic and non-tender, were mostly facial (around nostrils and mouth) and on fingers and dorsum of hands. (Figures $1 \& 2$ ).

Intraoral cavity was not affected and she was systemically well. The lesions progressed without remissions or exacerbations. Neither cryotherapy nor surgical excision resulted in any lasting effect. At eleven years, there was school refusal and social isolation due to disfigurement significantly affecting her lifestyle. Her family was not similarly affected

${ }^{1}$ Senior Professor in Paediatrics, Department of Paediatrics, Faculty of Medicine, University of Colombo, ${ }^{2}$ Registrar in Paediatrics, Lady Ridgeway Hospital for Children, Colombo

*Correspondence: manouri.senanayake@gmail.com (Received on 1 July 2014: Accepted after revision on 22 August 2014)

The authors declare that there are no conflicts of interest

Open Access Article published under the Creative

Commons CC-BY-NC-ND Licence. and parents were unrelated. A five month course of oral cimetidine $(40 \mathrm{mg} / \mathrm{kg} /$ day $)$ did not result in improvement. No side effects were reported by our patient during therapy or follow-up.

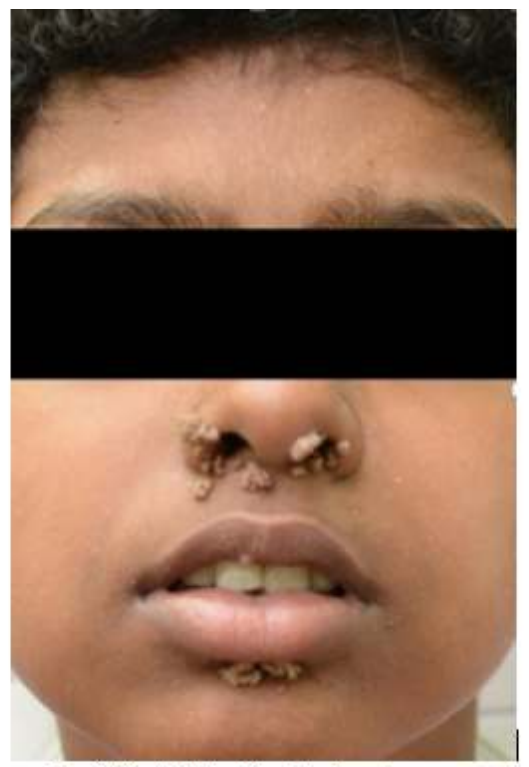

Figure 1: Wart-like fleshy lesions around mouth and nostrils

*Permission given by parents to publish photograph

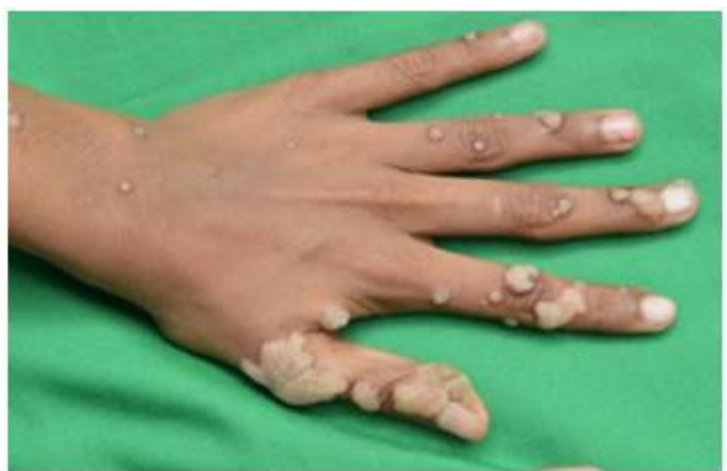

Figure 2: Hand showing extensive wart-like flattopped skin lesions on dorsum of hand and fingers

*Permission given by parents to publish photograph 


\section{Discussion}

EV usually originates in childhood or in early adulthood and a high risk of squamous cell transformation is present. Many treatment options have been tried with varying and often limited success $^{6}$. The lack of inducing inflammatory cytokines by HPV infections has formed the basis for aiming to facilitate the production of cytokines and immune modulatory effects of cimetidine has led to its usage in $\mathrm{EV}^{6}$. Cimetidine's inhibitory effect on $\mathrm{T}$ suppressor cell function and ability to depress mitogen-induced lymphocyte proliferation are among the mechanisms by which its usefulness has been justified. We found one report of marked improvement and no relapse at 6 month follow-up with cimetidine, while poor results and lack of efficacy has also been documented ${ }^{7,8}$. We discontinued cimetidine treatment after five months as there was no improvement of skin lesions. Psychological support, sun avoidance and close monitoring for early recognition of premalignant lesions were advocated while another treatment option such as zinc therapy is being considered ${ }^{9}$.

\section{References}

1. Roncalli de Oliveira W1, Neto CF, Rady PL, Tyring SK. Seborrheic Keratosis-like lesions in patients with epidermodysplasia verruciformis.: The Journal of Dermatology 2003; 30(1):48-53.

PMid: 12598709

2. Ansarin H, Tajziehchi L, Shaianfar N. A case of epidermodysplasia verruciformis with squamous cell carcinomas on non-sunexposed areas of skin. Archives of Iranian Medicine. 2007; 10: 261-3.

PMid: 17367237

3. Gober MD, Rady PL, He Q, Tucker SB, Tyring SK, Gaspari AA. Novel homozygous frameshift mutation of EVER1 gene in an epidermodysplasia verruciformis patient. Journal of Investigative Dermatology 2007; 127(8): 17-20.

http://dx.doi.org/10.1038/sj.jid.5700641
4. Sun XK, Chen JF, Xu AE. A homozygous nonsense mutation in the EVER2 gene leads to epidermodysplasia verruciformis. Clinical and Experimental Dermatology 2005; 30: 573-4

http://dx.doi.org/10.1111/j.13652230.2005.0 1858. $\mathrm{x}$

PMid: 16045695

5. Lazarczyk M, Pons C, Mendoza JA, Cassonnet P, Jacob Y, Favre M. Regulation of cellular zinc balance as a potential mechanism of EVER-mediated protection against pathogenesis by cutaneous oncogenic human papillomaviruses. Journal of Experimental Medicine 2008; 205:35-42 http://dx.doi.org/10.1084/jem.20071311 PMid: 18158319 PMCid: PMC2234378

6. Parton AM, Sommerville RG. The treatment of plantar verrucae by triggering cellmediated immunity. British Journal of Podiatric Medicine 1994; 131:883-6.

7. Micali G1, Nasca MR, Dall'Oglio F, Musumeci ML. Cimetidine therapy for epidermodysplasia verruciformis: Journal of the American Academy of Dermatology 2003; 48(2 Suppl):S9-10 http://dx.doi.org/10.1067/mjd.2003.111 PMid: 12582373

8. Walmar R.P. de Oliveira, MD, PhDemail, Cyro Festa Neto, MD, PhD, Evandro A. Rivitti, MD, PhD. The lack of a clinical effect of cimetidine in the treatment of epidermodysplasia verruciformis: Journal of the American Academy of Dermatology 2004; 50(6): e6 http://dx.doi.org/10.1016/j.jaad.2003.12.037 PMid: 15153919

9. Mun JH, Kim SH, Jung DS, Ko HC, Kim $\mathrm{BS}$, Kwon KS, et al. Oral zinc sulfate treatment for viral warts: An open-label study. The Journal of Dermatology 2011; 38:541-5. http://dx.doi.org/10.1111/j.13468138.2010.0 1056.x

PMid: 21352302 